\title{
Relative Clause Structure in Manipuri
}

\author{
Dr. Dhanapati Shougrakpam \\ Department of Linguistics, School of Humanities and Social Sciences, \\ Manipur University, Canchipur-795003, Manipur
}

\begin{abstract}
Manipuri is a T-B language of the Sino-Tibetan language family. It is the official language of Manipur, a north-eastern state of India.

The paper discusses three types of relative clause structure in Manipuri.

1. Internally headed relative clause(IHRC),

2. Externally headed relative clause(EHRC) and

3. Headless Relative clause (HRC).In the case of HRC, a sufficient referent capable of standing for the deleted head noun must be present such as- verb exhibiting nominal property, quantifying words, genitive constructions and demonstratives; this is situational and context sensitive. In cases where relative clause structure is formed with quantifiers, the quantifiers can only follow the head noun.

4. Keyword:Relative clause, noun phrase, internally headed relative clause, externally headed relative clause, headless relative clause.
\end{abstract}

\section{Introduction}

Relative clause is used when the reference of a noun cannot be clarified satisfactorily by any determiner. It is a sentence that is embedded into a noun phrase, and marked in some way as subordinate to the particular noun for which clarity of reference is sought.In Manipuri, relative clause is formed by addition of the nominalizer(NZR)-pə -bo to the embedded verb and a determiner (DET)- ədu 'that', əsi 'this'is used as a correlative marker as shown below.

(i) loykol do loysin satli

(ii) ləysin ədu phəjəy

When sentence (i) and (ii) is combined, the relativized sentence is formed as below

ləykoldəsatlibə ləysin ədu phəjəy

In the above sentence, loykoldə satlibə 'that is blooming in the garden' is a relative clause that is modifying the head nounləysin 'flowers'.

There are cases where the correlative marker can be dropped as in the case of quantifiers.

\section{Types of Relative Clause:}

Noun phrases consist of a potentially lengthy series of grammatical words whose relative order is fairly rigid and whose boundaries are well-defined. The relative clauses are discussed under the following types.

\begin{tabular}{|l|l|}
\hline Types & Functions \\
\hline Internally headed relative clause & The head noun occurs inside the relativized clause \\
\hline Externally headed relative clause & The head noun occurs outside the relativized clause \\
\hline Headless relative clause & The head noun is deleted \\
\hline
\end{tabular}

Table 1:Types of Relative Clause

(i) Internally headed relative clause:In internally headed relative clause, the head noun occurs inside the relativized noun phrase.

(ii) Externally headed relative clause:In externally headed relative clause, the head noun occurs outside the relativized clause. Here, the head noun can either precede or follow the relative clause.

(iii) Headless relative clause:In headless relative clause, the noun phrase head may be deletedif the remaining material is a sufficient referent (for example, a relational marker cannot be a sufficient referent). There must be some entity present which is capable of standing for the deleted head noun such as verb exhibiting nominal properties, quantifying words, genitive constructions and demonstrative. 
The three types of relative clauses are discussed as in the following structures:-

\section{Used of verb exhibiting nominal property:}

Examples:

a. ma-nə phurit əmə ləy

he-NOMshirt one buy

He bought one shirt.

b. phuritədu məcanupa nə ləw-khre

shirtDET son NOM take-ASP

The son took the shirt.

The three types of relative clause can be exemplified bycombination of sentence (a) and (b) as shown below.

Internally headed relative clause: In internally headed relative clause, the head noun phurit 'shirt' occurs within the noun phrase which is a relativized noun phrase.

$\begin{array}{llllll}\text { ma-nə phurit } & \text { əmə } & \text { ləy-rək-pə } & \text { du } & \text { məcanupa-nə } & \text { ləw-khre } \\ \text { he-NOMshirt } & \text { one } & \text { buy-DTC-NZR } & \text { DET } & \text { son-NOM } & \text { take-ASP }\end{array}$

The shirt that he bought is taken by his son.

Externally headed relative clause: In externally headed relative clause, the head noun phurit 'shirt' occurs outside the relativized clause which functions as a noun phrase. Here, the head noun phurit 'shirt' can either precede or follow the relative clause.
phurit ədu məcənupa-nə ləw-khre
he-NOM buy-DTC-NZR shirt DET son-NOM take-ASP

The shirt that he bought is taken by his son.

ii. phurit ma-nə ləy-rək-pə ədu məcanupa-nə ləw-khre

shirt he-NOM buy-DTC-NZR DET son-NOM take-ASP

The shirt that he bought is taken by his son.

Headless relative clause:The verbs exhibiting nominal property can stand as a sufficient referent for the deleted noun.

The modifying word ləyrəkpə 'bought' is a sufficient referent that is capable of standing for the deleted head noun phurit 'shirt' as in

$\begin{array}{lllll}\text { ma-nə } & \text { ləy-rək-pə } & \text { ədu } & \text { məcanupa-nə } & \text { ləw-khre } \\ \text { he-NOM } & \text { buy-DTC-NZR } & \text { DET } & \text { son-NOM } & \text { take-ASP }\end{array}$

His son took away what he bought.

2. Used of quantifying words:

Examples:

a. ənan khudinmək lak-y

child QTF come-ASP

b. Every child came.

child-PL DET DAT book give

The children were given books.

The three types of relative clause can be exemplified by combination of sentence (a) and (b) as shown below:-

Internally headed relative clause:

$\begin{array}{llllll}\text { lak-li-bə onan } & \text { khudinmək } & \text { to } & \text { layrik } & \text { pi } \\ \text { come-PRG-NZR child } & \text { QTF } & \text { EMP } & \text { book } & \text { give }\end{array}$

Every child that came were given books.

Externally headed relative clause:

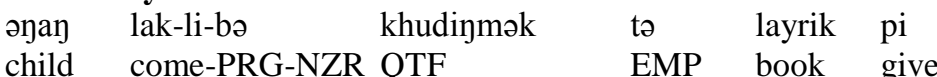

Every child that came were given books.

When quantifying words are used, the head noun can only precede the relative clause. 
In internally headed relative clause, the head noun ləysin 'flowers' occurs within the noun phrase which is a relativized noun phrase.

\section{Externally headed relative clause:}

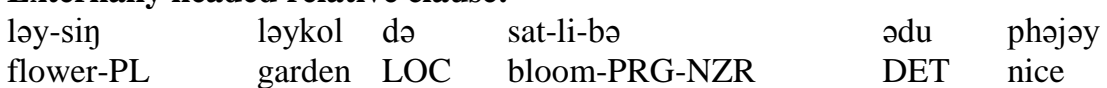

Flowers that are blooming in the garden are nice.

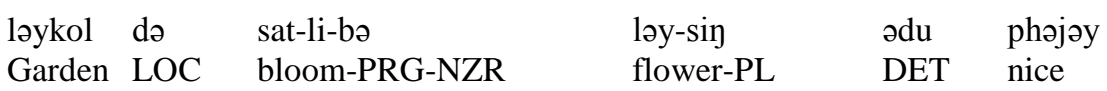

Flowers that are blooming in the garden are nice.

In externally headed relative clause, the head noun loysin 'flowers' occurs outside the relativized clause which functions as a noun phrase. Here, the head noun loysin 'flowers' can either precede or follow the relative clause.

\section{Headless relative clause:}

The demonstrative is a sufficient referent that is capable of standing for the deleted head noun.

Here the demonstrative adu 'that' can stand for the deleted head noun loysin 'flowers'.

$\begin{array}{llll}\text { ləykol do } & \text { sat-li-bə odu phəjəy } \\ \text { Garden } & \text { LOC } & \text { bloom-PRG-NZRDET } & \text { nice }\end{array}$

Those blooming in the garden are nice.

\section{Conclusion}

This paper is essentially an exploratory analysis of the structure of relative clause in Manipuri. The three types of relative clause ordering are discussed-internally headed relative clause,externally headed relative clauseand headless relative clause.In the case of externally headed relative clause, the head noun can either precede or follow the relativized clause. When quantifying words are used, the head noun can only precede the quantifiers and the correlative marker can be dropped.

These preliminary findings will hopefully serve as a basis for further advancement.

$\begin{array}{ll}\text { NOM } & \text { Nominative } \\ \text { DAT } & \text { Dative } \\ \text { DET } & \text { Determiner } \\ \text { EMP } & \text { Emphatic } \\ \text { ASP } & \text { Aspect } \\ \text { NZR } & \text { Nominalizer } \\ \text { QTF } & \text { Quantifier } \\ \text { PRG } & \text { Progressive } \\ \text { GEN } & \text { Genitive } \\ \text { BNF } & \text { Benefactive } \\ \text { DTC } & \text { Deictic } \\ \text { LOC } & \text { Locative } \\ \text { Pl } & \text { Plural }\end{array}$

\section{Abbreviations}

\section{References}

[1]. DeLancey, Scott (1989) 'Relativization and nominalization in Tibetan and Newari.' Presented at the 19th Annual Meeting of the International Conference on Sino-Tibetan languages and Linguistics.

[2]. DeLancey, Scott (2002) 'Relativization and nominalization in Bodic.' Proceedings of the Twenty-Eighth Annual Meeting of the Berkeley Linguistics Society: Special Session on Tibeto-Burman and Southeast-Asian Linguistics, pp. 55-72

[3]. Herring, Susan C. (1991)'Nominalization, relativization, and attribution in Lotha, Angami and Burmese.' Linguistics of the Tibeto-Burman Area, Volume 14:1-SPRING 1991. 